Vol. 7, No. 1, 2017

\title{
125-TH ANNIVERSARY OF ELECTRICAL ENGINEERING EDUCATION AND SCIENCE IN LVIV POLYTECHNIC (1891-2016)
}

\author{
Petro Stakhiv, Serhiy Rendzinyak, Oksana Hoholyuk \\ Lviv Polytechnic National University, Lviv, Ukraine; \\ spg@polynet.lviv.ua,emd@polynet.lviv.ua,oph@polynet.lviv.ua
}

(C) Stakhiv P., Rendzinyak S., Hoholyuk O., 2017

\begin{abstract}
The article deals with the history of foundation, development and modern state of Department of Theoretical and General Electrical Engineering of Lviv Polytechnic National University. The role of the Department in the development of European electrical science, its main achievements and prospects of further development are discussed.
\end{abstract}

Key words: electrical engineering, anniversary, education process, history of science.

\section{Foundation and development of electric engineering in Lviv Polytechnic}

Lviv Polytechnic National University is one of the oldest institutions of higher education in Ukraine. History of its development begins with formation of a tricycle Real School, like European schools of that time, in Lviv in 1816; the school belonged to oldest academic schools of Europe. In November 1871, the Academy was awarded the status of the institution of higher education by its Rector. At the same time, the faculty of mechanical engineering (machine-building) was organized.

The end of the nineteenth century is notable for formation and development of electrical engineering practical application of theoretical achievements in the field of electricity and magnetism. With practical purpose, a transformer was used for the first time in 1876 by P. N. Yablochkov for power supply for electric arc lamps. After improvement of the incandescent (filament) lamp and after creation of many elements of electrical equipment, the famous American inventor Thomas-Alva Edison constructed heavy duty (as to those times) power generators, and in 1882 put into operation thr first thermal power plant. The notable electromechanic M. Dolivo-Dobrovolskiy during his work in enterprises of Edison's electrotechnical company (Germany) made a whole range of important discoveries and inventions. He suggested a three-phase power transmission system, and in 1888 he constructed the first generator of three-phase current with rotational magnetic field; he also developed an asynchronous motor with short-circuited rotor (1890) which even nowadays is notable for its economy and simplicity. These properties and, as a consequence, low price became the reason why the asynchronous motor became to be widely used; and with this, the three-phase system became widely used. Ath the same time, the intensive development the structure of the first three-phase transformer, and in 1981 the wye (Y) and delta $(\Delta)$ circuits of connections the generators and motors; he had constructed the first power transmission line for threephase current $170 \mathrm{~km}$ long.

At the same time, famous Ukrainian scientist Ivan Puliuy, professor of experimental and engineering physics of German high technical school in Prague initiated an individual course of lectures in electrical engineering with practical training classes. His speeches constantly gave rise to great interst and often were refered to in popular scientific journals. He has made a considerable contribution into investigation of cathode and X-rays. In the field of electrical engineering, he has introduced the use of constant component for calculation of circuits of non-sinusoidal current, he suggested a method for measuring the phase difference of sinusoidal current, he is a patentee of a range of electrical devices.

Under the condition of rapid introduction of new achievements in electrical engineering into industry there arose an urgent need in training scientific and technical specialists in new subjects in the Poytechnical school in Lviv, the scholl was known all over Europe. Such a name the school was given in 1877-1879 with the right of high technical school, and the school was included into the network of the academic schools of AusroHungarian empire. There were taught students from Russia, Germany, Romania, France, Turkey and other countries in the school.

Electrical engineering, as an individula subject was for the first time teached as early as in $1887 / 88$ year by Franciszek Dobrzyński, private docent.

On the $27^{\text {th }}$ of October 1890 Ministry of education of Austro-Hungarian empire founded extra-ordinary department of electrical engineering, which was to be 
properly staffed. The Board of Professors (now Academic Council) expressed the opinion that the best candidate was Roman Dzieślewski, a graduate of the Technical Academy in Lviv, who had acquired knowledge in structure of electrical machines.

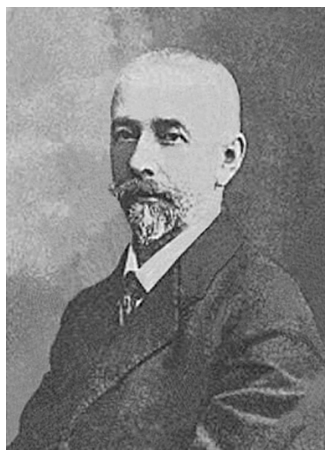

Prof. Roman Dzieślewski (1863-1924).

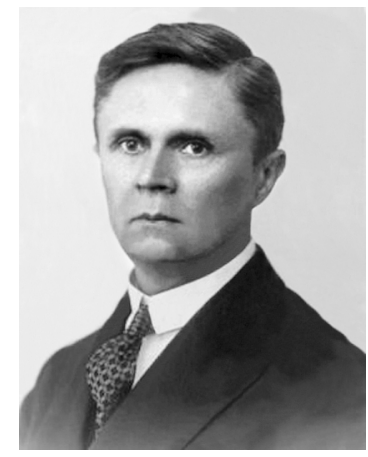

Prof. Gabriel Sokolnicki (1877-1975).
Roman Dzieślewski, who was awarded the title of extraordinary professor on the $27^{\text {th }}$ of September 1891 , began to deliver his lectures in the same year. He had also organized a modern electrotechnical laboratory, for which machines and measuring devices were purchased.

In those times, the academic year in Polytechnic was traditionally begun from the report of rector, who was elected for a year, from the newly elected rector's speech on the curriculum, and from the problem report of one of leading professors. The new 1892/93 academic year had begun from the report of prof. Roman Dzieślewski "View on the transmission of power by electricity", which was an entirely new problem of engineering of these days.

In 1901/02 academic year, R. Dzieślewski was elected rector of the Politechnic school; in the next academic year vice-rector. During 1894/96, 1904/08 academic years he worked as a dean of the department of machines desigh, in 1896/98, 1908/11 academic years as vice-dean.

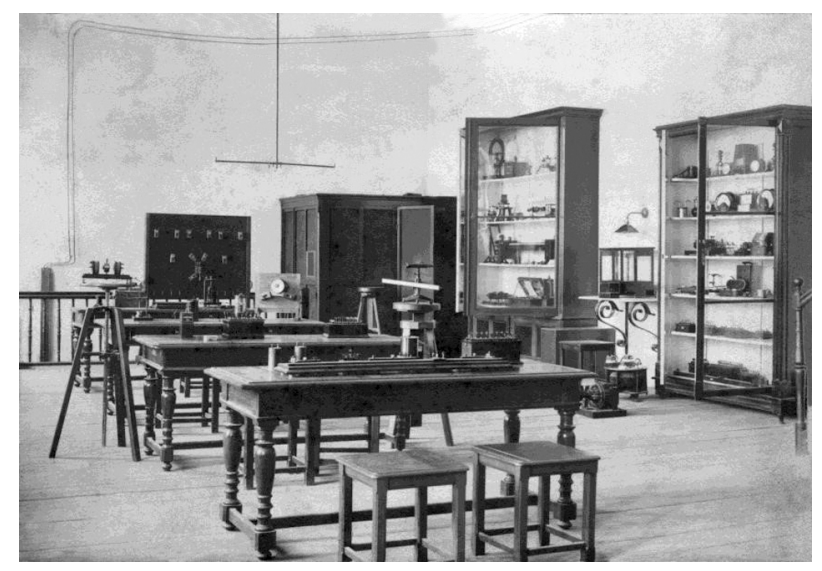

Laboratory of electrical engineering (now Room 115 of Main Building). Photo of February 28, 1902.
In 1913, ordinary professor Aleksander Rothert began to manage the ordinary department of structural electrical engineering (elektrotechniki konstrukcyjnej). At the same time, a paid associate professor position of basics of electrical engineering (zasad elektrotechniki) headed by Gabriel Sokolnicki), who in 1920/21 academic years became extraordinary professor in electrical engineering. When the Polish power replaced the Austro-Hungarian in Halychyna, the Polytechnical school was reorganized: since 1920 it was called Lviv Polytechnic, and the department of electrical engineering obtained the new name - Department of General Electrical Engineering (1921).

Extraordinary department of Electrical Measurements headed by professor Dr. Kazimierz Idaszewski, department of Electric Power Generation and Distribution (wytwarzania i rozprowadzania energii elektrycznej) headed by extraordinary professsor Gabriel Sokolnicki, who in 1924/25 became ordinary professor, and in 1931/32 academic year he was elected Rector of Lviv Polytechnic (he leaved and worked in Lviv till June 1975, then he died at $99^{\text {th }}$ year of his life).

He has carried out almost 30 projects, mainly of electric power stations, in particular for the towns of Sambir, Drohobych, Stryi, Kremenets, Krynytsia, Krosno, Nadvirna, Przemyśl, Rivne, Khodoriv, Zhovkva, Rava-Ruska, and others. Besides, he developed the project of Lviv region electric power supply network as well. In 1917-1918 G. Sokolnicki supervized the reconstruction of installations of electric illumination and transition of the whole electricity supply network of Lviv to AC three-phase networks.

\section{Formation of Lviv Electrical Engineering School}

In 1921, the High Lviv Polytechnic School was renamed to Lviv Polytechnic, which already trained electrotechnical engineers. Since 1923, fundamental articles on basics of the electric circuits theory written by D. Sc. Stanislaw Fryze, who worked at the department of General Electrical Enginering, were published. In these works, his own original approaches to complicated electrical problems are presented. $\mathrm{He}$ creatively approached the theory of alternating current circuits with the use of circuit diagrams, he proposed the system of arrowization of voltages and currents in the DC and AC circuits. The scientific activity of Stanislaw Fryze and the published work, his defended doctor's disseratation in 1923 drew the attention of the Senate of the Lviv Polytechnic. In October 1926, he was promoted to the position of extraordinary professor of the Department of General Electrical Engineering at Mechanical faculty. Besides academic work, professors of Lviv Polytechnic actively participated in discussions of practical application sphere. For example, in 1929 in "Технічні 
вісті" (Technical Journal) there was a controversy about Government concession for electrification of Poland by V. A. Harimann's firm. Prof. G. Sokolnicki and Prof. K. Idaszewski, eng. Maurizi Altenberg and Prof. S. Fryze noted that it was not only benefit from that project, but also harm from dependence of Poland on foreign capital, that has led to the dismissal of that "case".

In 1931, a scientific controversy about the concept of active, total, and reactive powers (which were suggested by prof. S. Fryze) in electric circuits arose. Prof. S. Fryze innovations and those of his colleagues from the Department, in particular, docent Izaak Rosenzweig concerning the theory of powers and the theory of multi-phase circuits have enriched theoretical electrical engineering, considerably simplified analysis of electric circuits and helped in developing the theory of circuits with sinusoidal and non-sinusoidal voltages and currents. These scientific achievements have promoted Prof. S. Fryze to top of the European electrical engineering science. In the interwar time, the Lviv Polytechnical School, together with the German electrical engineering school, was a leading school in Europe. The German school was headed by prof. Fritz Emde from Shtuttgard and by prof. J. Wallot from Berlin High School.

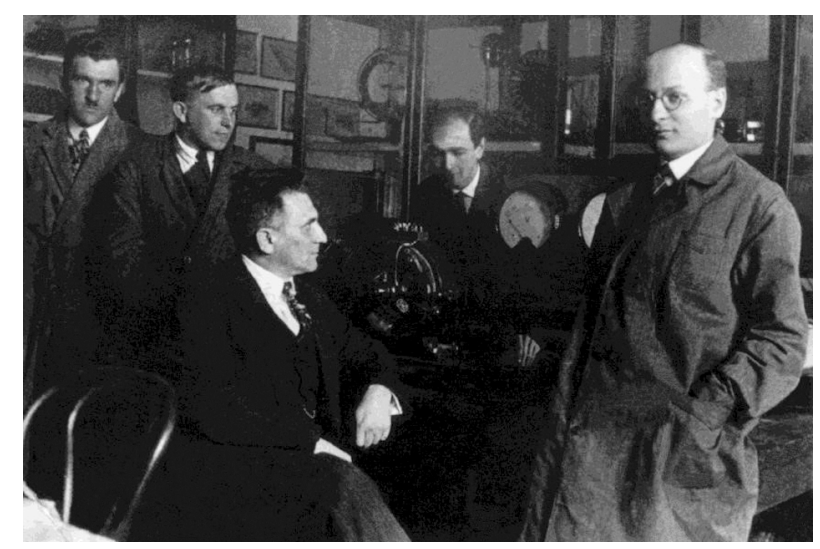

Prof. Stanislaw Fryze with his colleagues from Department of General Electrical Engineering of Lviv polytechnic 1931/32 academic year.

From the left: Aleksander Kaszuba - senior laboratory assiestent; Master engineer. Rudolf Pończa - senior assistant;

Prof. Stanislaw Fryze; Dr. enginner Izaak Rosenzweig (this docent died in Lviv during German-Fscist occupation in 1941; Master-engineer Naurycy Hüttner - senior asistent.

Besides lectures for students of Lviv Polytechnic, Prof. S. Fryze delivered special popular-science lectures for adults and high school youth: "Application of high voltages in electrical engineering" with demonstration of voltages up to $300 \mathrm{kV}$; "On electric shock hazard". The second lecture avoked so great interest among the inhabitants of the city of Lviv, that it was repeated. It caused such a considerable influx of customers into the different establishments with electrical devices that electricians could not repair the lamps, irons, stoves, tiles, and other electrical devices in due time.

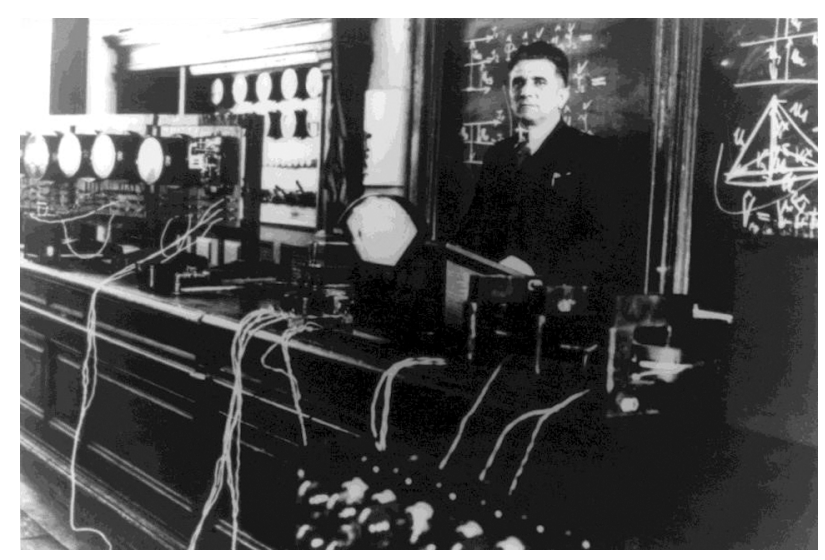

Demonstrational unit of high voltages up to $300 \mathrm{kV}$ in popular-science lectures delivered by Prof. S. Fryze in November 10, 1936, in March 8. 15, 1937; Room IV (now room 114 of Main Building).

After the annexation of West-Ukrainian lands to the Soviet Ukraine, the Higher Attestation Commission of Ukraine under Sovnarkom of the USSR confirmed the S. Fryze's status as professor of the department of electrical engineering of Lviv Polytechnical Institute, where he continued to work with reduced teaching load. During the German occupation, the Lviv Polytehnical Institute was renamed to State professional courses, the activity of which was extremely limited. With return of Soviet power to Lviv in 1944, the educational process in Lviv Polytechnical Institute is gradually being established. Prof. S. Fryze takes an active part in this restoration when working during 1943/44 and 1944/45 academic years in the position of dean of faculty of electrical engineering. Under his supervising the work of the Institute's workshops was restored; the electric power to the machine tools was supplied not from the city electric power supply network, but by means of the asynchronous generator transformed from the motor with electric drive taken from the Krupp's motor. The buildings of Lviv Polytechnical Institute were also illuminated by that generator. Prof. S. Fryze did his best to restoration of work of other electric power facilities of Lviv as well.

After the World War II, the process of repatriation of Poles to Poland was launched. Prof. S. Fryze was invited by two Polish establishments of higher education to head a department of general electrical engineering. He decided to work in Politechnika Śląska in Gliwice, and in 1946 he left for Poland, where he restored and developed Polish science of electrical engineering. 
Prof. S. Fryze became one of the best Polish theorists in electrical engineering and gained world-wide recognition.

On the path of revival of the Department of Electrical Engineering

In July 1944, the Red Army liberated the ancient Lviv from German-Fascist invasion; and as early as in August, a new reinforcement came to Lviv Polytechnic. There came the graduates of Polytechnic Mykola Maksymovych, Volodymyr Kochan, Yuriy Sitnytskyi, Vasyl Kovalchuk-Ivaniuk, into the department of the restored electrical engineering faculty to further glorigy their Alma Mater with the fruitful scientific and educational work. There also came Yuriy Velychko, who graduated from Politechnika Gdańska. Howewer, in Lviv Polytechnical Institute the fate of the overwhelming majority of graduated from Lviv Polytechnic Ukrainians, and especially of graduated of high schools of Europe, failed. Some of them perished in battles for freadom of Ukraine, some of them in battles for enslavement of Ukraine, others were shot in prisons of NKVD and Gestapo. Many of them became strangers in foreign lands, and many of them have glorified foreign sciences...

In 1946 the Department of electrical engineering was headed by Doctor of Technical Sciences, Professor Oleksandr Kharkevych - specialist in electrical acoustics, disciple of Leningrad scientific school, representative of a generation of intellectuals peers of the XX century. As a man of all-round scientific talent, great personality, prof. O. Kharkevych rather favourably influenced the formation of a new department. Around him, gifted young scientists and engineers -candidates of technical sciences, associate professors Yuriy Neliubov, O. Oliferenko, engineers Mykola Maksymovych, Serafym Kyrpatovskyi, Borys Rymar, Mykola Nikolayev, Bohdan Blazhkevych, Petro Hasdayka, Bentsion Shvetskyi, Hryhoriy Denysenko, Vitaliy Sihorskyi rellied, later on, they became associate professors and professors. The creative enthusiasm of this small team, a devotion to common work, exhauting, but with inspiration work during the hungry and cold year of 1944 ensured the organization of educational process as early as in September.

Prof. O. Harkevych has established a scientificresearch laboratory of electroacoustics at the Department and signed an agreement on the development of precision equipment for measuring of acoustic signals and parameters by the order from the P. Lebedev Physical Institute of Academy of Sciences of the USSR. In this laboratory, scientific and pedagogical staff for the Department were trained. He also supervised the postgraduated course under the Department. M. Maksymovych was the first who graduated from it and successfully defended his dissertation; then M. Maksymovych was head of the Department of Theoretical and General Electrical Engineering (TGEE), later on he became rector of Lviv Polytechnical Institute (LPI), rector of Lviv State University named after Ivan Franko (LSU). In the same year, Prof. O. Kharkevych organized a student's scientific club.

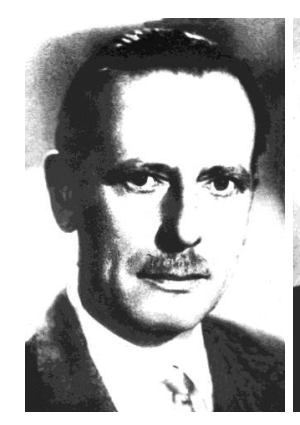

Oleksandr

Kharkevych,

Academician

of Academy

of Sciences

of the USSR

(1904-1965).

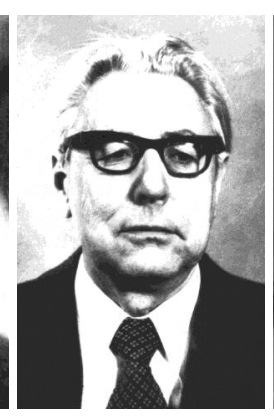

Prof. Georgiy Pukhov,

Academician of Ukrainian Academy of Sciences (1916-1998).

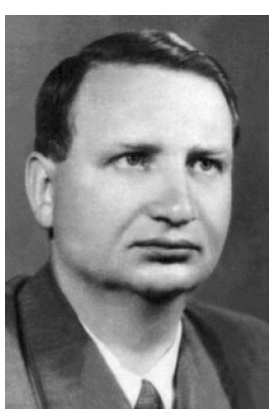

Prof. Mykola Maksymovych (1914-1981).

When in 1948 his monograph "Theory of Transducers" on electroacoustics was published and he was elected Corresponding Member of the USSR Academy of Sciences for his especially fruitful work, he letf for Kyiv and then for Moscow. In the capital of the USSR, he was appointed director of the Institute of Problems of Information Transmission and was elected Academician of the Academy of Sciences of the USSR.

In 1948, the Department of Theoretical and General Electrical Engineering (TGEE) was headed by the talented disciple of Tomsk Polytechnical Institute, participant of the War, candidate of technical sciences, associate professor Georgiy Evgenyevich Pukhov. After svere wound in 1942, and after long-term treatment, he defended his candidate dissertation, and since 1944 he became to work at the Department of Electrical Machines. In 1947 Prof. O. Kharkevych invited the associate professor G. Pukhov who headed the Department of Electrical Machines, to deliver lectures on the course of theoretical fundamentals of electrical engineering at his department (work part-time).

Associate professor G. Pukhov was the first who at the department paid attention to prof. Fryze's works. As early as in 1947, he introduced the system of unambiguous mathematical description of electric circuits, multicoordinate system of branches, currents, and voltages of a circuit, marking them with arrows (so called "arrowization"). This system was also propagated 
by disciples of prof. S. Fryze - M. Maksymovych, B. Blazhkevych, and other lecturers; this contributed to formation of conscise thinking and successful study of electrical engineering by students. At the TGE department, the theory of power of multi-phase systems has also found a cerratin development as a response to the dissertation work of the Dr. Engineer I. Rozenzweig. Exactness in their mathematical description and diversity of views on the issues are characteristic of these works.

In those years, in the theory of electrical engineering, intensive investgations aimed at formalization of methods of electriccircuits analysis were conducted (H. Kron, S. Mason, K.-L. Kouts, E. Zelach, E. Maerovich at all). In the best style of traditions of Lviv Electrical Engineering School, at the TGEE department, at a new stage, investigations just according to this trend were deployed. Among the scientific works in the 1940-ies, the achievements, in particular, of Associate Professor G. Puchov and V. Sigorskyy should be noted, who made a contribution to the generalized theory of the four-port networks; the theory was elaborated by the associate professor (future professor) Yu. Velychko, Head of the Department of Radioengineering. A result of these works contributed to transition to the theory of the multi-ports. Later on, the theory was elaborated by V. Sigorskyy and B. Blazhkevych.

Associate Professor G. E. Pukhov always payed great attention to quick publishing of works. Even under hard conditions of post-war years he established publication of "Научных записок ЛПИ (электротехническая серия)" (Scientific papers of LPI, electric engineering series); and in 1960s, he, in cooperation with Prof. M. Maksymovych, was the founder of the scientific collection "Теоретическая электротехника" (Theoretical Electrical Engineering), which gained international recognition.

In 1950, associate professor G. Pukhov returned to Tomsk, where in 1952 he defended his doctoral dissertation. Later on, he worked in Taganrog Radioengineering Institute, then in Kyiv in the Institute of Cybernetics of Ukrainian Academy of Sciences, in Institute of Electrodynamics of Ukrainian Academy of Science. Then he headed Institute of Problems of Modeling in Power Engineering of Ukrainian Academy of Sciences established by him in Kyiv. This talented scientist - laureate of State Award of the USSR, academician of Ukrainian Academy of Sciences - has reached the heights of science, he developed a method of subsystems, a basics of complex calculus, T-transformations; he has created new methods of calculation of nonlinear electric circuits, which have considerably widened knowledge and possibilities in this highly important field. Great achievements are made by
Professor G. Pukhov in the field of electronic modelling and new computational devices and systems. A whole generation of scientists has been educated on his scientific works in Ukraine and abroad; among them, there are many doctors of sciences and academicians.

The period of 1950-1964 is associated with the name of head of the department, Doctor of Technical Sciences, Prof. Mykola Maksymovych - former student of Pre-war Lviv Polytechnic. Natable personal traits and, first of all, his high self-discipline of M. Maksymovych became a guarantee of his multifaced activity. After his appointment (1953) as Rector of the Institute, he constantly combined his scientific work with administrative work and public activity.

It was time of rapid development of the Department. M. Maksymovych initiated the work of authors' teams of the TGE Department in order to introduce new methods and means of programmed teaching, in particular, examining machines into educational process. In late 1950s and early 1960s, there were developed methodological materials and created means of programmed knowledge control, prepared for publication manuals on programmed teaching in the courses of theoretical fundamentals of electrical engineering. This system was successfully introduced into educational process.

The main scientific trend which had been formed due to natural development of the whole previous activity of the department was the trend of formalized methods of electric circuit analysis. The two approaches to this problem were developed: deductive approach, which was adhered to by B. Blazhkevych; and inductive approach, which was developed by M. Maksymovych. Head of the department of theoretical fundamentals of radioengineerin, Doctor of technical sciences, Prof. Yuriy Velychko cooperated with the Department. His scientific works in the theory of radioelectronic circuits were closely correlated with the both aforesaid approaches of the TGEE. Actively, sometimes even vigorously, scientific seminars of the Department proceeded; there participated specialists of a range of departments of electrical engineering specialization in these seminars.

In 1950s, in courses of theoretical fundamentals of electrical engineering Prof. M. Maksymovych and Associate Professor S. Kirpatovskyi in-depth teached the section of non-linear electric circuits (NEC), it contributed to scientific development concerning this important problem, both in 1950s and during next decades. Later on, Prof. M. Maksymovych suggested an original mathematical model of electric circuits with the last number of variables - so called "decisive" ones. He generalized and formalized the theory of electric circuits 
with multi-ports, he developed topological methods of analysis of such type circuits.

In 1961, the M. Maksymovych monograph “Линейные электрические цепи и их преобразование" (Linear electric circuits and their transformation) and the B. Blazhkevych monograph "Основні методи аналізу лінійних електричних кіл" (Main methods of electric circuits analysis) were published. The Lviv Electrical Engineering School became one of the leading schools in the USSR and the world in the field of formalized methods of linear electric circuits analysis.

In 1960, B. Blazhkevych headed the Department of Theory of Circuits in the Phisical-Mechanical Institute of the Ukrainian Academy of sciences, he continued his work at the TGEE Department at the same time. It was a the most fruitful period of scientific activity of this talented scientist. He complited his investigations in the field of formal methods of analysis of linear circuits offered a highly efficient method of system-oriented graphs. His generalization of formalized methods and comprehensive estimation of domain of their effectiveness are especially valuable. B. Blazhkevych is the author of over ten monographs, over three hundred articles, great number of preprints and authors certificates. The latter are, mainly related to problems of aerospace engineering, on which he also worked very fruitfully.

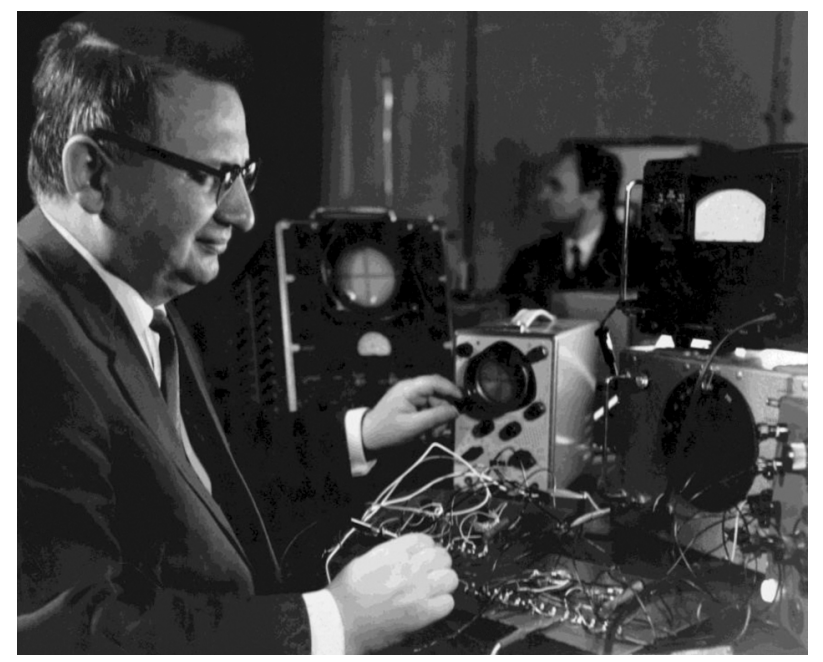

Prof. Mykola Maksymovych in laboratories of Ivan Franko Lviv State University.

When working in the position of Rector of LPI in 1964, the Government appointed prof. M. Maksymovych to the position of Rector of Ivan Franko Lviv State University (LSU). accepted this honorable appointment and hesded LSU till the end of his life. Feeling isolation from his basic science - electrical engineering, after hard long-term work he established a Department of
Theoretical Fundamentals of Electrical Radio Engineering (TFERE), the potential of LSU was elevated by this. In this Department the gifted scientists were gathered. Among them, the especially notable personality was Prof. Lev Synytskyi, Doctor of Techinal Scienses, (head of this Department in 1978-1990).

In works of professors M. Maksymovych and B. Blazhkevych the most perfect modern formalized methods of electric circuits analysis were developed. They belong to the most famous representatives of Lviv Electrotechnical School.

During 1964-1975 the TGEE department was headed by Associate Professor Serafym Ivanovych Kìrpatovskyi, candidate of technical sciences, graduate of Kharkiv Polytechnical Institute, captain-engineer, who had passed hard ways of of the World War II with a burdain of a signal man. In these years, the staff of the Department kept the traditional trends of activity in the educational process, in scientific-methodological, and in traininig academic and teaching personnel.

In those times, there were prepared for publication the tutorials for programmed study of subjects "Сборник программированных задач по теоретическим основам электротехники" (Collection of problems on theoretical fundamentals of electrical engineering) edited by N. G. Maksimovich and I. B. Kudelko - Lvov: Vyshcha Shkola, 1976. -504 p. and, eventually, the first written in Ukrainian, collection of problems on electrical engineering "Загальна електротехніка. Збірник програмованих задач" (General Electrical Engineering): collection of programmed tasks edited by P. Haazdayka Kyiv: Vyshcha Shkola, 1976. - 200 p.

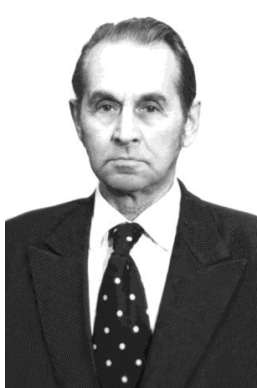

Prof.

B. Blazhkevych), (1912-1986).

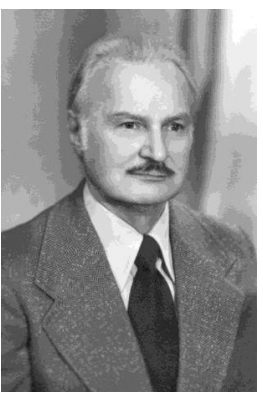

Prof. Serafym Kirpatovskyi (1913-2009).

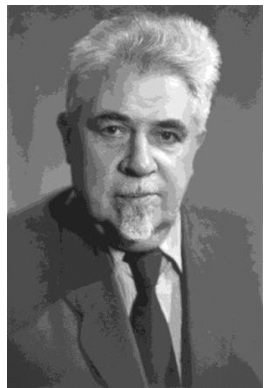

Prof. Tykhon Hubenko (1896-1971).
In the same years, together with the Department of Theoretical Fundamentals of Electrical Radioengineering (TFERE) of Ivan Franko Lviv State University, Methodical Commission of the USSR Ministry of Higher Education, and Institute of Machine Engineering and Automation of USSR Academy of Sciences, the Department became a co-founder of scientific and 
technical journal "Теоретическая электротехника" "Theoretical electrical engineering". The members of the TFERE department were both authors of articles and active members of Editorial Board of the Jouornal (I. Lysytska, S. Kirpatovskyi).

The foundation of the НДС-4 laboratory as a subdivision of Research sector of LPI in 1959 contributed to extension of the subjects of scientificresearch work in the TGEE department. The organizer and leader was Head of the Department of Electrical Machines and Apparatus prof. Tykhon Hubenko, doctor of technical sciences. НДС-4 laboratory conducted automation of technological processes in oil fields of Carpathian region, including development of instrumentation. In these developments, specialists of TGEE department also actively participated.

In 1964, associate professor S. Kìrpatovskyi founded the scientific-resarch laboratory НДЛ-47 under the TGEE department and on the basis of НДС-4; in that laboratory, under his leadership scientific works in creation and improvement of trancducers and complicated measuring devices for selective measurement of individual components of multicomponent streams were carried out. The staff of НДЛ-47 laboratory headed by its member Viktor Rudenko, candidate of technical sciences, has created modern measuring transducers for fluid washing solutions, which were used during drilling of the wells (viscousimeter, density-meter). Specialists investigated the problem of flow rates measuring of heterogeneous streams, they developed a system of control over loadsin metal-working machines, hey also carried out other orders for industry.

In the years when the Department was headed by a graduate of LPI by1957, Associate Professor Oleksandr Shehedyn (1975-1986), graduate of Lviv Polytechnical Institute (who at the same time worked as Dean of the preparatory department), there find their continuation the traditional trends of its activity: educational process was being improved, scientific methodological work continued, scientific-research work and training academic and teaching personnel increased.

An the initiative and with active participation of Associate Professor O. Shehedyn computerization of educational process was initiated. In a short time, the corresponding mathematical means was developed, and it was introduces an the level of student independent educational and scientific work.

The scientific and methodical relationsof the TGEE Department with relevant departments of the higher educational institutions of Ukraine, in republics of the USSR and abroad were expanding. The publication of the Journal "Теоретическая электротехника" ("Theoretical Electrical Engineering") contributed to these relations. The scientic-research work of the Department which was focused on using machine methods of analysis of complicted electrical and electronic circuits was considerably intensified. There was founded the Researchand-Production Association (RPA) "Електронпроект" (Electroengineering Design) on the basis of the Lviv Specialized Design Office (SDO) "Мікроприлад" (Microdevice), for microelectronics and device making; it was affiliated to Physico-Mechanical Institute of Ukrainian Academy of Sciences (department of electric circuits theory) and to TGEE department.

Within the framework of RPA "Електронпроек" there were carried out several works on contracts; due to this, there was created a complex of machine programs for designing analog assemblies of control and measuring equipment, in particular, such problems were solved: analysis of transient and steady-state modes of electronic circuits under the possibility of powering from pulse sources and presence of topological degeneration; compatible matrix parameters approximation of multiport by means of fractional-rational operator functions and its implementation by means of simplified linearized calculational models; formation of the fractional-rational operator functions of complex linear electronic circuits using topological analysis and calculation of sensitivity respectively to elements of the circuit on their basis; modelling of multi-port by means of fractional-rational functions using interpolational method and others.

In the НДЛ-47 laboratory, a whipshop signalling device for a powerful turbine has been developed, and the developed with participation of НДЛ-47 laboratory signalling device for fixed revolution of the turbine's rotor was exhibited in Exhibition of Economic Achievements in Moscow.

Prof. T. Hubenko's disciple associate professor V. Chaban, who on the basis of the investigatigations has published the monographs "Основы теории переходных процессов электромеханических систем” (Bases of transient processes of electromagnetic systems) (1981), "Методы анализа электро-механичских систем" (Methods of analysis of electromechanic systems) (1985 p.), worked on methods and means of computer engineering concerning electrical machines systems.

Taking into consideration the significant achievements of the Department in its activity, according to the decision of the Collegium of the Ministry of Education, the TGEE Department is appointed as reference department in West-Ukrainian Region; and the head of the Department was elected a member of the AllUSSR Union scientific and methodological council on theoretical fundamentals of electrical engineering.

New Milestones of the Department

In October 1986, the Department of Theoretical and General Electrical Engineering became headed by 
Professor Volodymyr Perkhach, Doctor of Technical Sciences, who worked in this position until the autumn of 1996. During 1955-1964, he worked in the Department of TGEE; and in the period from 1971 to 1983, he headed the department of electric systems and networks of the faculty of electrical power engineering. Here, he formed a new scientific trend - mathematical modeling and optimization of electric power systems with valve devices. On the basis of this trend, the modern Lviv scientific school of electric power engineering was formed.

To ensure the educational process in the subject TFEE and in other subjects of electrical engineering, especially intensive scientific and pedagogical work aimed at formation of their theoretical and methodological bases, as well as publication of corresponding textbooks and manuals was conducted.

Prof. V. Perkhach has developed methodological bases of modelling of dynamic electromagnetic circuits of electrical power engineering systems on the basis of implicit backward differentiation method (BDF). In this method, he developed a theory of dynamic electromagnetic circuits, he also developed the inversion of their models. On this basis, the author, together with his disciples, has formed discrete models of almost all main elements of electric power systems in different coordinates. In particular, there are developed the bases of a new generation of highly adequate mathematical and digital models which are sufficiently presented in the monograph "Енергетичні системи 3 електропередачами та вставками постійного струму” (Power systems with electrical transmission and links of high voltage direct current) by A. Shydlovskyy, V. Perkhach and O. Skrypnyk. In 1991, for scientific achievements (officially for the textbook "Математичні задачi електроенергетики" (Mathematical problems of electrical power engineering)) V. Perkhach was awarded the honorary title of State Prize of Ukraine laureate in the field of science and technology. He was elected (together with Prof. V. Chaban) academician of the Academy of Engineering Sciences of Ukraine, a member of the Institute of Electrical and Electronic Engineers (IEEE).

In the Department, great attention was paid to revival and development of Ukrainian scientific and technical terminology, to appropriate language style. In this trend, the Department has had significant achievements. Thus, in this period V. Perkhach published 7 textbooks and tutorials in Ukrainian. In 1990, with the participation of TGEE department and lecturers from departments of electromechanical and electric power engineering faculties, there was published “Короткий російсько-український електротехнічний словник" (Brief Russion-Ukrainian Dictionary on Electrical Engineering) edited by V. Perkhach.

In 1991, the K. Popper International Foundation awarded the scietific-terminological laboratory under the TGEE department a grant for carrying out the project "Terminology Date Bank in Ukraine". For active introduction of Ukrainian language into educational process, the dictionary "Англо-український електротехнічний словник" (English-Ukrainian Dictiory on Electrical Engineering) edited by V. Chaban was published.

On the basis of the Department the First International Scientific and Technical Conference on Mathematical Modeling in Electrical Engineering and Power Engineering (Lviv, September 19-21, 1995), which became permanent, was initited and held. Three international confereces on problems of Ukrainian Scientific and Technical Terminology in 1992-94 and International Scientific Conference "Problems of Ukrainian Terminology" in 1996 was held.

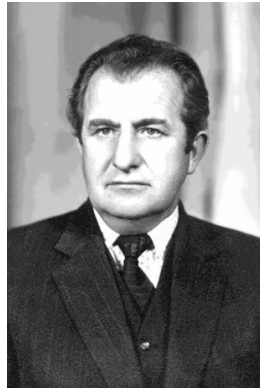

Assoc. Prof.

O. Shehedyn

(1933-2007).

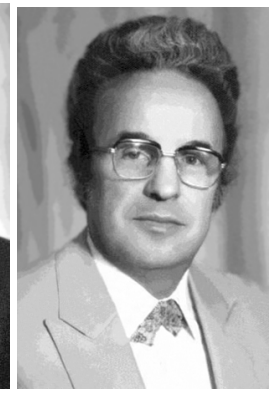

Prof. Volodymy
Perkhach

(1929-2005).

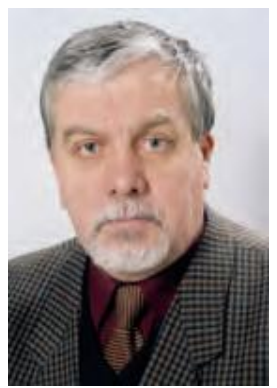

Prof. Petro

Stakhiv

(born in 1948).
In autumn 1996, the Department was headed by Prof. Petro Stakhiv, Doctor of Technical Sciences, who in 1991-1996 headed the Department of Theoretical Fundamentals of Electrical Radio Engineering (TFERE) of Lviv Ivan Franko State University.

For students, during these times, a considerable number of textbooks and tutorials approved by Ministry of Education and Science of Ukraine was published; among there were the following: S. Malynivskyi “Загальна електротехніка" (General Electrical Engineering); P. Stakhiv, V. Korud, O. Hamola “Основи електроніки: функціональні елементи та їх застосування" (Fundamentals of Electronics: Functional Elements and Their Application); "Збірник задач 3 теоретичних основ електротехніки. Частина 1" (Collection of Tasks on Theoretical Fundamentals of Electrical Engineering, Part I) by A. Vorobkevych, V, Malyar, R. Sovyn, M. Sokolovskyi, P. Stakhiv, O. Shehedyn. Besdides, we shoul mention the books: O. Shehedyn, V. O. Malyar "Теоретичні основи 
електротехніки. Частина 1" (Theoretical Bases of Electrical Engineering, Part 1); V. Malyar "Теоретичні основи електротехніки. Електричні кола" (Theoretical Bases of Electrical Engineering. Electric Circuits); "Теоретичні основи електротехніки. Збірник задач. Частина 2: навч. посібник" (Theoretical Bases of Electrical Engineering. Collection of Tasks. Part II) / M. Howykowycz, A. Vorobkewych, N. Musykhina, O. Hamola, V. Horiachko, V. Maday, S. Rendzinyak, M. Sokolovskyi, P. Stskhiv, Ya. Chepurnyi, M. Dyvak; “Дискретне макромоделювання в електротехніці та суміжних областях: монографія" (Discrete Macromodeling in Electrical Engineering and Related Fields of Science) by P. Stakhiv, Yu. Kozak, O. Hoholyuk.

In the Department computer training methods were being actively introduced into the educational process. In pericular, a laboratory is founded, and methodological support on basics of microprocessor engineering is developed, a cycle of simulation laboratory works on electric circuits theory, a software and guidelines on the use of computer means during execution of individual tasks by students are developed. The foundation of the affiliated to the Department modern computer laboratory equipped due to the help of Rectorate and Directorate of Institute of Power Engineering and Control Systems considerably contributed to this.
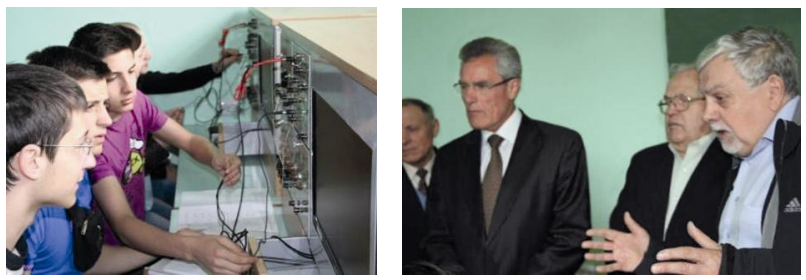

Rector of the University Yu. Bobalo and Director of Institute of Power Engineering and Control Systems O. Lozynsky inspecting the new computer laboratory on electric circuits theory (May 8, 2014).

International Cooperation of the Department was developed. Thus, within the framework of the Europeinian Union Project's "PHARE/TACIS" the contracted work "Development of the Sotware Shell for Educational and Methodological Center of the Ecologicaly Clean Power Engineering" under the "Clean Energy" Program was carried out. Cooperation Agreements with Warsaw, Wroclaw and Zielona Gora Universities of Technology (Poland) and HiessenFriedberg University of Applied Sciences (Germany) were signed.

The result of the close cooperation with Polish scientists was organization of Joint Ukrainian-Polish Workshops on "Actual problems of Theoretical Electrical Engineering: Science and Didactics" in 1999 andi 2001 in Alushta (Ukraine) and in 2000 in Solino (Poland), as well as international conferences "Computational Problems of Electrical Engineering" which were held in 2002 in Zakopane (Poland) and in 2003 near Buchach (Ukraine). Now we have involved Czech and Slovak Scientists into such cooperation; due to common efforts there are carried out international scientific and technical conferences "Computational Problems of Electrical Engineering" (CPEE) in different countries under the auspices of IEEE. Scientists of the Department participated in the work of all these conferences, beginning with the first in 1999, as the organizers and co-organizers.

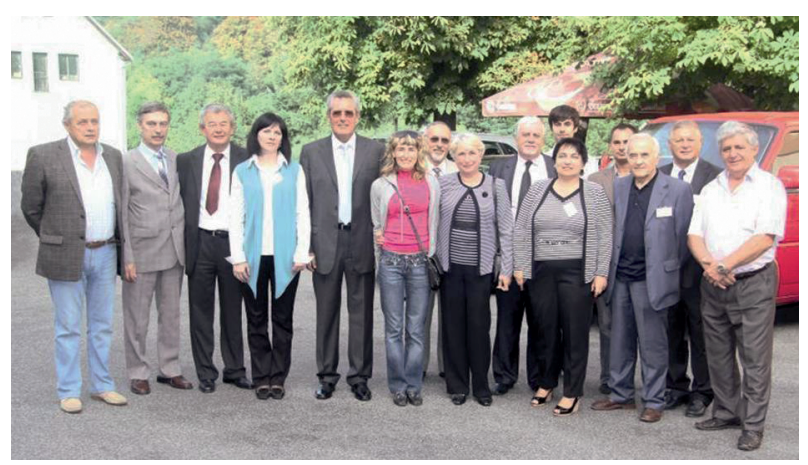

Participants of the International scientific and technical conference "Computational Problems of Electrical Engineering”, 4 - 6 September 2013, Roztoky u Křivoklátu (Czech Republic).

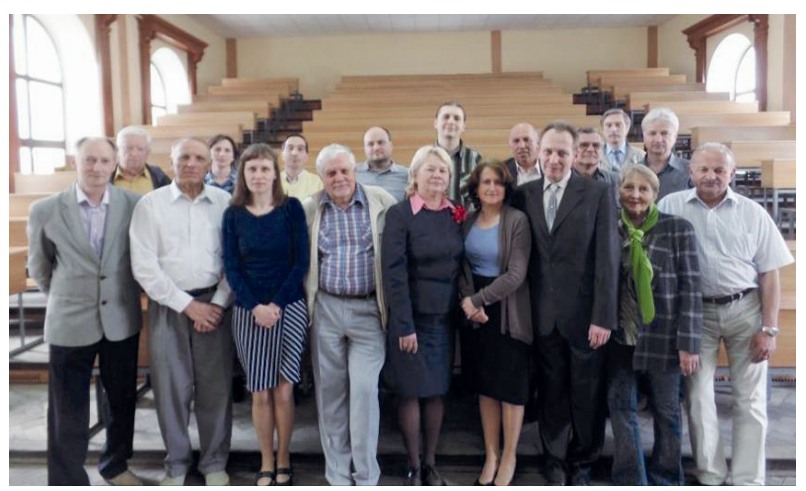

Staff of Department of Theoretical and General Electrical Engineering in room. 114 (Main Building) May 26, 2016.

Due to efforts of the departmnet nowadays 22 subjects, among which are classic: "Theoretical Fundamentals of Electrical Engineering", "Electric and magnetic Circuits Theory", "General Electrical Engineering", "Electronic Circuits Theory", and Special Courses "Research Methods of Electromechanical Transducers, Physical and Mathematics Experiment", "Optimization Methods in Problems of Electrical Engineering" are supported. Lecturers of the Department teach more than 1500 students, they have the possibility to conduct laboratory courses in 5 laboratories: 
Theoretical Electrical Engineering, General Electrical Engineering, Electrical Machines, Electronics and Microprocessor Technology, Computer Equipment.

\section{References}

[1] Rendzinyak S., Tkachuk V., Seheda M., et al., Origins and development of electrical engineering education and science in Lviv Polytechnic (18912016). To the 125-Anniversary of Lviv electrical engineering school. Lviv, Ukraine: Publishing House of Lviv Polytechnic National University, 2017. (Ukrainian).

\section{ДО 125-РІЧЧЯ ЕЛЕКТРОТЕХНІЧНОӦ ОСВІТИ І НАКИ У ЛЬВІВСЬКІЙ ПОЛІТЕХНЦІ}

\author{
Петро Стахів, Сергій Рендзіняк, \\ Оксана Гоголюк
}

Подано історію заснування, розвитку та сьогодення кафедри торетичної та загальної електротехніки Національного університету “Львівська політехніка". Висвітлено роль кафедри у становленні європейської електротехнічної науки, iї основні досягнення та перспективи подальшого розвитку.

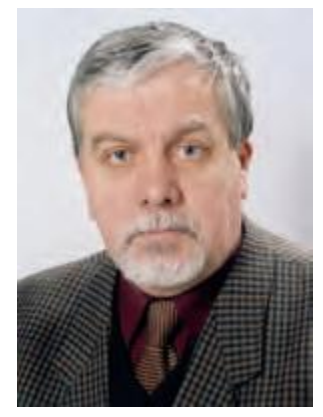

Petro Stakhiv - Ph.D., D.Sc., Professor, graduated from Physical Faculty of Lviv State University and received the M.Sc. degree in radiophysics and electronics. In 1975 he received the Ph.D. degree in theoretical electrical engineering. In 1992 he received D.Sc. degree in the same specialty. Since 1973 till 1996 he worked at the Department of Theoretical Fundamentals of Electrical and Radioengineering at Lviv State University. In 1996 he became a Head of Department of Theoretical and General Electrical Engineering at Lviv Polytechnic National University. His scientific interests are mainly concerned with mathematical modeling and simulation of dynamic processes in electrotechnical systems, numerical methods, optimization methods, system theory, and parallel programming.

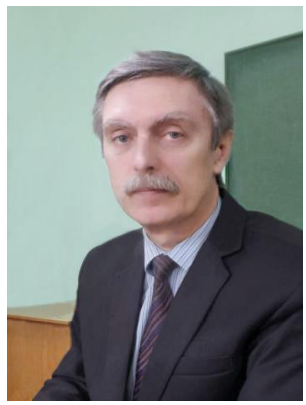

Serhiy Rendzinyak graduated from Ivan Franko State University, Lviv, Ukraine as specialist in the field of Radiophysics and Electronics. He defended his Ph.D. dissertation thesis at Ivan Franko State University, Ukraine, and DSc dissertation thesis at Lviv Polytechnic National University in Theoretical Electrical Engineering. He worked at Lviv Polytechnic National University as Associate Professor from 1997 to 2008; since 2008 he holds the position of Professor at the Department of Theoretical and General Electrical Engineering, Lviv Polytechnic National University.

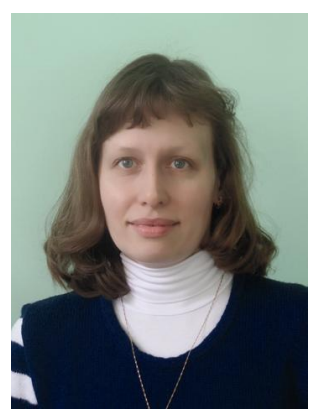

Oksana Hoholyuk - Ph.D., Ass. Professor, graduated from physical faculty of Ivan Franko State University of Lviv. Starting from 2004 she has been working at the Department of Theoretical and General Electrical Engineering of Lviv Politechnic National University. Her scientific interests are focused on mathematical modeling and simulation of dynamic processes of electric circuits and systems. 